\title{
Characteristics of L-Citrulline Transport across Rat Small Intestine In Vitro
}

\author{
J. V. VADGAMA AND D. F. EVERED \\ Division of Medical Genetics, Department of Pediatrics, Harbor-UCLA Medical Center, UCLA School of \\ Medicine, Torrance. California 90502 [J.V.V.) and Department of Biochemistry. King's, Queen Elizabeth, and \\ Chelsea Colleges, University of London, London, United Kingdom [D.F.E.I
}

\begin{abstract}
The amino acid L-citrulline is an important intermediate of urea cycle and a key precursor for arginine biosynthesis. We have examined the characteristics of citrulline transport across the everted sacs of the rat small intestine. Our studies suggest that the optimal site of citrulline absorption is middle to lower ileum. It shows active transport, and this transport is predominantly $\mathrm{Na}^{+}$ dependent. Its uptake is significantly inhibited by ouabain, dinitrophenol, sodium azide, and sodium cyanide. Kinetic estimation reveal an apparent substrate concentration at $1 / 2$ maximum velocity of $4.10 \pm 0.86 \mathrm{mM}$ and a $V_{\max }$ of 18.7 $\pm 1.66 \mu \mathrm{mol} / \mathrm{g}$ wet weight tissue $/ 30 \mathrm{~min}$. Analog inhibition studies suggest that citrulline may share the neutral brush border system described for the mucosal brush border membranes of the rabbit jejunum or a system analogous to system ASC described for nonepithelial cells and for basolateral membranes of certain epithelia. In conclusion, the rat small intestine has developed a specific carrier-mediated, $\mathrm{Na}^{+}$-dependent pathway for citrulline absorption. (Pediatr Res 32: 472-478, 1992)
\end{abstract}

\section{Abbreviations}

LPI, lysine protein intolerance

$K_{t}$, substrate concentration at $1 / 2$ maximum velocity NBB, neutral brush border

The amino acid L-citrulline is an important intermediate of the ornithine cycle (1). It plays a major role as a precursor of arginine and urea. The uptake and metabolism of citrulline is of importance in the inborn disorders of the ornithine-cycle enzymes, namely citrullinemia (2). Citrullinemia is caused by a defective argininosuccinate synthetase (EC 6.3.4.5), an enzyme that converts citrulline to argininosuccinic acid in the ornithine cycle. The most profound biochemical findings are hyperammonemia and an elevated citrulline concentration in the blood, cerebrospinal fluid, and urine. Clinically, there are various symptoms ranging from a serious derangement with convulsions, coma, and death to an apparently benign biochemical disorder with no clinical symptoms (2). Citrulline is excreted in abnormal amounts in the renal Fanconi syndrome and Hartnup disorder, both disturbances of amino acid transport $(3,4)$.

Rajantie $e t$ al. (5) reported that citrulline may play an important role in replenishing the diamino acids "lost" in patients with LPI. This autosomal recessive defect of diamino acid transport

Received February 21, 1992; accepted May 21. 1992.

Correspondence: J. V. Vadgama. Division of Medical Genetics, Bldg. E-4, Harbor-UCLA Medical Center, 1124 W. Carson St.. Torrance, CA 90502.

Supported by the Lord Dowding Fund for Humane Research, London, UK and Grant DK 39147 from the National Institutes of Diabetes and Digestive Diseases, National Institutes of Health, United States Public Health Service. is characterized by massive diaminoaciduria, especially lysinuria, with hyperammonemia after high protein intake. The defect is known to occur in kidney, liver, and intestinal cells (5). Oral loading of diamino acids in homozygote subjects showed a negligible increase in plasma concentrations of the loaded diamino acids. On the other hand, after citrulline load, plasma citrulline levels rose similarly in control and homozygotes, suggesting that citrulline absorption was normal in patients with LPI (5). Rajantie et al. (5) suggested the ornithinopenic hyperammonemia of LPI can probably be prevented by supplementing dietary protein with citrulline.

The mechanisms of citrulline transport across intestinal and renal tubules, however, are not understood. Evered and Nunn (6) showed that citrulline passes across the everted colon sacs of the rat intestine down the concentration gradient. Lin et al. (7) suggested that citrulline could be transported by a "neutral amino acid transport system"; however, no data were given. We now provide a detailed report on the mechanisms of citrulline transport across the rat small intestine and discuss its physiologic significance.

\section{MATERIALS AND METHODS}

Animals. Male albino (Wistar) rats, $180-240 \mathrm{~g}$ body weight, were starved overnight but given water ad libitum.

Intestinal preparation. The preparation was the modified method for the everted sac of small intestine (8). The technique involves the use of short lengths of intestine turned inside out, filled with fluid, and tied at both ends. The solutions bathing the intestinal surfaces were prepared by dissolving the respective amino acids in oxygenated Krebs-Ringer phosphate buffer (9). Everted sacs were prepared from several animals; at least three rats were killed for each experiment. The number of sacs used for each experiment varied according to the following requirements: (1) Initially, to determine the optimal site for uptake of each amino acid, the whole of the small intestine was used, from the pyloric end to the point where the intestine joins the caecum (the ileo-caecal joint). In this case, about 10 to 12 sacs were prepared. (2) To study the absorption of single amino acids, about two to four sacs were prepared from the selected region of the small intestine. (3) Finally, to study the effect of inhibitors, six to eight sacs were prepared from the selected region of the small intestine. In this case, the test solution or the test solution containing the inhibitor was injected into alternate sacs along the length selected. The overall preparation was completed within 10 to 15 min after the animal's death. Two sacs, each containing $0.4 \mathrm{~mL}$ of either the test solution alone or test solution with the inhibitor, were placed in a $50-\mathrm{mL}$ flask containing $15 \mathrm{~mL}$ of the incubation medium. Incubation time was reduced to $30 \mathrm{~min}$ to avoid histologic damage (10). For experiments in which transport against the concentration gradient was studied, the concentration of L-citrulline in the serosal fluid and the mucosal fluid was identical. In experiments in which transport down the concen- 
tration gradient was studied, $0.4 \mathrm{~mL}$ of Krebs-Ringer phosphate buffer, $\mathrm{pH} 7.4$, was substituted for the test solution within the sacs. After gassing for 2 to 3 min with $95 \% \mathrm{O}_{2}-5 \% \mathrm{CO}_{2}$, the flasks were sealed and shaken at $37^{\circ} \mathrm{C}$ for $30 \mathrm{~min}$ at 80 oscillations $/ \mathrm{min}$. In our experiments, $80 \mathrm{cycles} / \mathrm{min}$ was considered to be a reasonable rate that would reduce the effect of unstirred water layer and avoid morphologic damage to the brush border membranes.

Effect of $\mathrm{Na}^{+}$ions. To investigate the effect of $\mathrm{Na}^{+}$ions on $\mathrm{L}-$ citrulline transport, $\mathrm{K}^{+}$was substituted for $\mathrm{Na}^{+}$in both the preincubation and incubation media. $\mathrm{NaCl}$ and $\mathrm{Na}_{2} \mathrm{HPO}_{4}$ were replaced with equimolar amounts of $\mathrm{KCl}$ and $\mathrm{K}_{2} \mathrm{HPO}_{4}$. For these experiments, the intestine was rinsed with isotonic $\mathrm{KCl}$ rather than isotonic $\mathrm{NaCl}$.

Amino acids. Unless otherwise stated, all amino acids were purchased from Sigma Chemical Co. (St. Louis, MO). The purity of the test compound was checked by one-dimensional thin-layer chromatography (11) using a solvent system that gave reasonable separation of ornithine cycle intermediates. The solvent consisted of isopropyl alcohol-formic acid-water (75:12.5:12.5 vol/vol/ vol). L-Citrulline was detected by ninhydrin $(0.2 \mathrm{~g}$ ninhydrin in $95 \mathrm{~mL}$ ethanol and $5 \mathrm{~mL}$ collidine) followed by Ehrlich's reagent ( $2 \% \mathrm{wt} / \mathrm{vol}, p$-dimethylaminobenzaldehyde in $5 \% \mathrm{HCl} \mathrm{vol} / \mathrm{vol}$ ). The purity of the amino acids including citrulline was additionally checked with the automatic amino acid analyzer (Locarte Instrument Co., London, UK).

Analytical methods. Protein was removed by isoelectric precipitation (12). L-Citrulline was assayed by a colorimetric method that is specific for the determination of carbamoyl or ureido compounds (13). Absorbency measurements were made at 466 nm using a Unicam (Hitachi, Japan) SP1 800 spectrophotometer.

Calculations. The concentration ratio for everted sacs was defined as the fraction concentration of test compound in serosal fluid + concentration of test compound in mucosal fluid. Theoretically, a ratio greater than 1.0 indicates active transport against a concentration gradient. The rate of transference into the serosal fluid was calculated by subtracting the amount of test compound originally placed in the sac from that amount found analytically within the sac at the end of the incubation period. The final result was expressed as $\mu \mathrm{mol}$ absorbed/g wet $w t / 30$ min.

Determination of fluid or water transport. Because the amount of amino acid transport into the serosal fluid was expressed in relation to the wet weight of the sac determined at the end of the incubation period, it was necessary to investigate the effect of weight changes due to water of fluid uptake into sacs. The sacs with ligatured ends were carefully blotted (Whatman \#54) and weighed before and after the incubation period on a torsion balance graduated up to $1000 \mathrm{mg}$ (Griffin and George Ltd., London, UK).

Statistical analysis. Statistical significance was obtained from $t$ test. In each case, a probability value of $p<0.05$ was considered significant.

\section{RESULTS}

Site of optimal uptake. Figure 1 shows that the transmural transport of $1 \mathrm{mM}$ L-citrulline is greatest at a distance between 60 and $90 \mathrm{~cm}$ distal to the pyloric end (a similar pattern was observed with uptake at $10 \mathrm{mM}$ L-citrulline). This region of the small intestine was used for later experiments with L-citrulline.

Active transport. Active transport is known to occur when substances are transported against their concentration gradient. In this study, transport against the concentration gradient was investigated by determining the final serosal to mucosal ratio. Our results in Table 1 show that the lower the initial amino acid concentration the higher the concentration ratio attained at the end of the experimental period. Active transport against the concentration gradient was shown at $1 \mathrm{mM}$ and slight transport at $5 \mathrm{mM}$, but none at $10 \mathrm{mM}$ initial L-citrulline concentration.

Effect of substrate concentration of $\mathrm{Na}^{+}$substitution. Figure 2

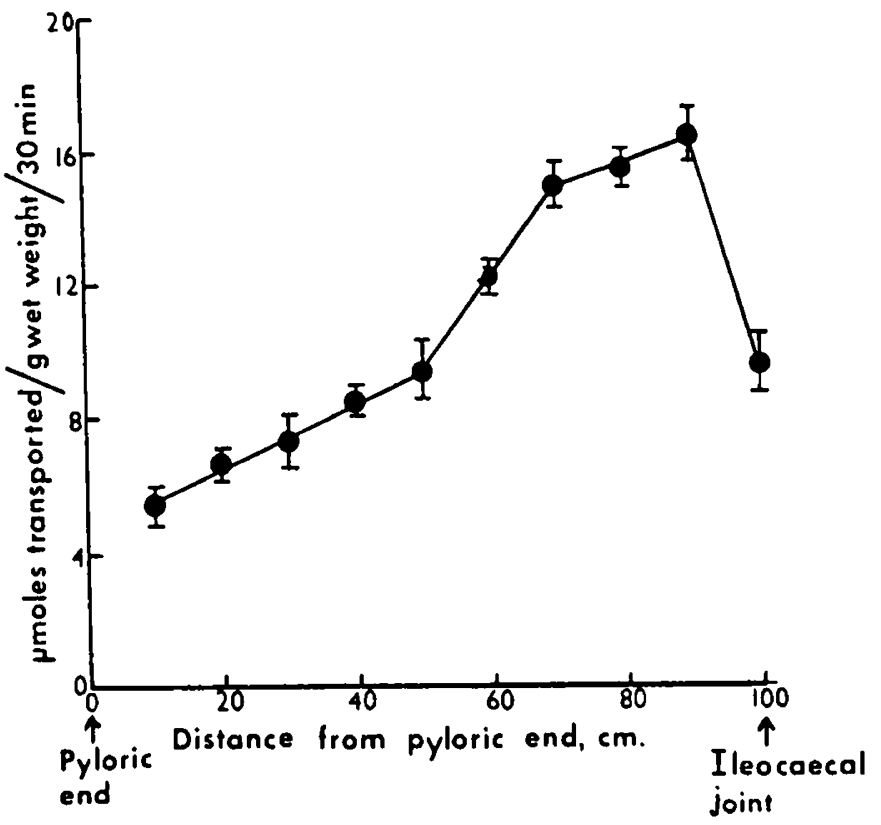

Fig. 1. Transmural transport of $1 \mathrm{mM}$ l.-citrulline across the different regions of the rat small intestine using everted sacs. The distance was measured in $\mathrm{cm}$ from the pyloric sphincter. Each point represents the mean transport \pm SEM of five experiments. A time course from 5 to 60 $\mathrm{min}$ revealed linear uptake up to $50 \mathrm{~min}$ (data not shown). We subsequently selected $30 \mathrm{~min}$ as a convenient time interval for all subsequent measurements for Figures 1-3 and Tables 1-4.

Table 1. Absorption of L-citrulline against concentration gradient by sacs of everted small intestine of rat

\begin{tabular}{cc}
\hline $\begin{array}{c}\text { L-Citrulline concentration } \\
(\mathrm{mM})\end{array}$ & $\begin{array}{c}\text { Final concentration ratio } \\
\text { (serosal/mucosal)* }\end{array}$ \\
\hline 1 & $1.43 \pm 0.07(6)$ \\
5 & $1.20 \pm 0.01(7)$ \\
10 & $0.98 \pm 0.08(6)$ \\
\hline
\end{tabular}

* Mean values \pm SEM of the number of experiments in parentheses. determined at the end of an experimental period of $30 \mathrm{~min}$.

shows the downhill transport of L-citrulline with increasing substrate concentration at the mucosal site. The rate of uptake was linear up to $2 \mathrm{mM}$ initial concentration and saturated soon after. Curve $a$ shows net uptake over $30 \mathrm{~min}$ in $\mathrm{Na}^{+}$buffer, and curve $b$ demonstrates the $\mathrm{Na}^{+}$-dependent component of uptake after subtracting net uptake in curve $a$ from $\mathrm{Na}^{+}$-independent plus nonsaturable uptake in curve $c$. These results suggest that citrulline uptake in rat small intestine is predominantly $\mathrm{Na}^{+}$dependent. The $\mathrm{Na}^{+}$-independent uptake in $\mathrm{K}^{+}$buffer is nonsaturable, at least up to $10 \mathrm{mM}$.

Determination of kinetic constants. Figure 3 shows a Lineweaver-Burk plot for the $\mathrm{Na}^{+}$-dependent uptake of $\mathrm{L}$-citrulline before and after correction for the nonsaturable component (14). The value for the apparent $K_{t}$ was $4.10 \pm 0.86 \mathrm{mM}$, and that for the apparent $V_{\max }$ was $18.7 \pm 1.66 \mu \mathrm{mol}$ transported $/ \mathrm{g}$ wet weight tissue/30 min.

Possible metabolic loss and percentage of recovery. Recovery experiments were performed to investigate any possible metabolic loss of citrulline during the $30-\mathrm{min}$ incubation period. In this case, the total concentration of citrulline inside the sac (serosal fluid) and in the outside medium (mucosal fluid) was measured before and after $30 \mathrm{~min}$ of incubation. At $1 \mathrm{mM}$ citrulline concentration, we obtained $96.6 \pm 0.44 \%$ recovery $(n=10)$. This value is the mean \pm SEM of the number of experiments in parentheses. The remaining 2 to $3 \%$ could be bound to the tissue or lost during tissue manipulation. This 


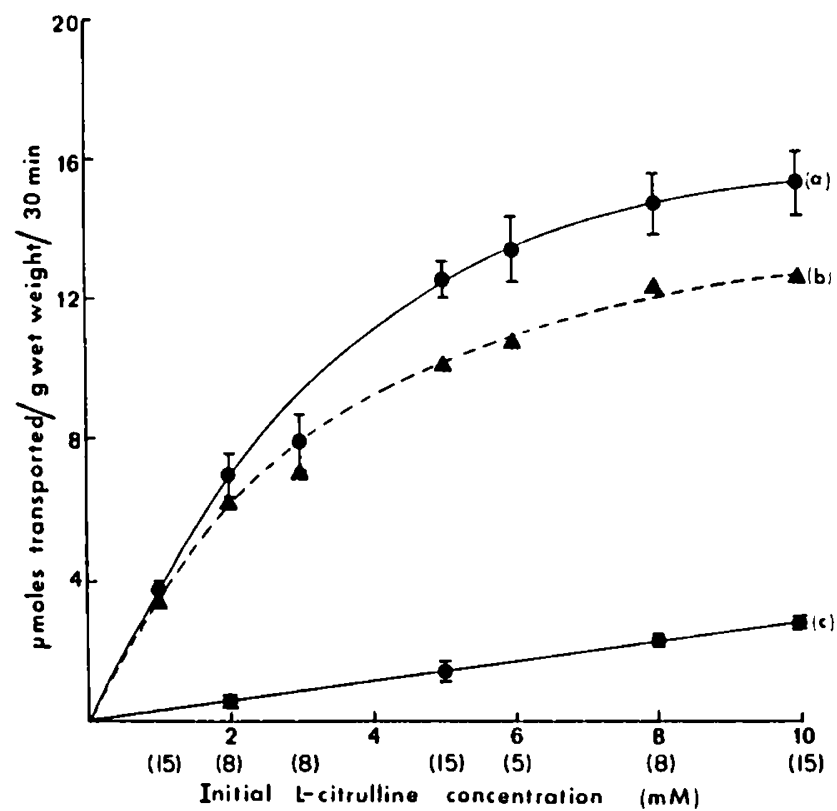

Fig. 2. Effect of concentration on the absorption of L-citrulline across the rat small intestine. Curve $a$ shows the uptake before correction for $\mathrm{NA}^{+}$-independent and nonsaturable uptake (curve c), and curve $b$ shows the uptake after correction. Values are means $\pm S E M$ of the number of experiments in parentheses.

amount was not measured and was subsequently neglected in our calculations.

At the end of the incubation period, both serosal and mucosal samples were analyzed for the possible presence of ornithine cycle intermediates by thin-layer chromatography and with the amino acid analyzer (Locarte Instrument Co., London, UK). Absence of any detectable intermediates suggest negligible metabolic loss of citrulline.

Water transport and its effect on intestinal absorption of $\mathrm{L}$ citrulline. With the everted sac preparation, it was possible that the uptake of water could significantly affect the rate of citrulline transport. The amount of water transported into each sac was determined by weighing the filled sacs with wet ligatures before and after the experimental period. Our results showed that on the average $(n=10) 43.8 \pm 5.24 \mathrm{mg}$ of water was transported into each sac. This is the mean \pm SEM of the number of experiments in parentheses. However, when the wet weight of the tissue was corrected for the amount of water transported, we did not observe any significant $(p<0.10)$ difference in the uptake of $5 \mathrm{mM}$ citrulline. Note that the uptake value for a given experimental sac was corrected for water accumulation by the same sac. The values were $8.14 \pm 0.53(n=8)$ and $9.35 \pm 1.54$ $(n=8) \mu \mathrm{mol}$ transported/g wet weight tissue/ $30 \mathrm{~min}$ for uncorrected and corrected uptake, respectively. The values are the mean \pm SEM for the number of determinations in parentheses.

Effect of ouabain and metabolic inhibitors. Transport of Lcitrulline against its concentration gradient and a decrease in the absence of $\mathrm{Na}^{+}$suggested that the transmural transport of citrulline was $\mathrm{Na}^{+}$and energy dependent. We examined the effect of ouabain, a cardiac glycoside that affects the $\mathrm{Na}^{+}-\mathrm{K}^{+}$-dependent ATPase, in the following manner. It has been suggested that ouabain is effective only when it has access to the serosal side of the small intestine (15-18). We therefore first examined mucosal inhibition. In this case, the inside of the sac was filled with 0.4 $\mathrm{mL}$ of oxygenated Krebs buffer and the outside solution (mucosal) consisted of $15 \mathrm{~mL}$ of $2 \mathrm{mM}$ L-citrulline with $1 \mathrm{mM}$ ouabain. The results showed $27.5 \%$ inhibition with statistical significance of $p<0.025$ (Table 2). Next, serosal inhibition was investigated. In this case, the inside of the sac (serosal) contained $0.4 \mathrm{~mL}$ of oxygenated Krebs buffer with $1 \mathrm{mM}$ ouabain and the outside (mucosal) solution contained $15 \mathrm{~mL}$ of oxygenated buffer with $2 \mathrm{~mL}$ L-citrulline. Here we observed a greater inhibition of up to $47 \%$ (Table 2 ). The difference was highly significant ( $p<$ $0.005)$ when compared to mucosal inhibition $(p<0.025)$. We then examined the combined effect of mucosal and serosal inhibition. In this case, ouabain was present on both sides of the sac. The results show greater inhibition than that found with ouabain on a single site ( $52 \%$ inhibition with $p<0.005)$.

It has been suggested that ouabain takes at least $15-20 \mathrm{~min}$ to penetrate the serosal surface and exert its inhibitory effect on the $\mathrm{Na}^{+}-\mathrm{K}^{+}$ATPase located on the basolateral surface of the epithelium, a factor that may account for the differences in its inhibitory effects. To investigate this possibility further, we examined the effect of preincubation with ouabain. In this case, a segment of the intestine was incubated in Krebs buffer containing $1 \mathrm{mM}$ ouabain for $30 \mathrm{~min}$ at room temperature. A control segment of the intestine was placed for the same period in Krebs buffer without ouabain. Everted gut sacs were then prepared from each

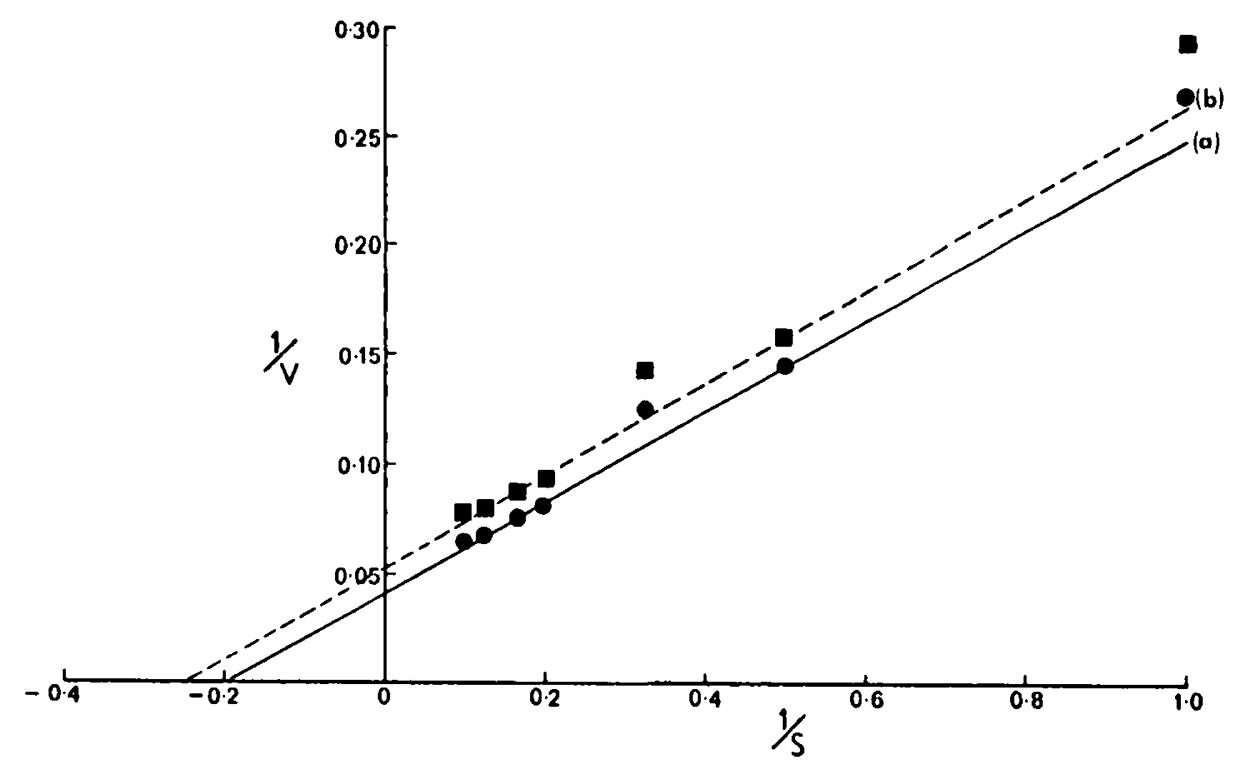

Fig. 3. Lineweaver-Burk plot for the absorption of $\mathrm{I}$-citrulline across the rat small intestine. Line $a(\Theta)$, before correction for $\mathrm{Na}^{+}$-independent and nonsaturable uptake: line $h,(\mathbb{O})$, after correction. Both lines are drawn through intercepts of $\mathrm{K}_{\mathrm{t}}$ and $\mathrm{V}_{\max }$ obtained from weighted least-square regression analysis (14). 
Table 2. Effect of $1 \mathrm{mM}$ ouabain on intestinal absorption of 2 $m M$ L-citrulline

\begin{tabular}{|c|c|c|c|c|}
\hline $\begin{array}{c}\text { Type of } \\
\text { inhibition }\end{array}$ & $\begin{array}{l}\text { Control with- } \\
\text { out ouabain* }\end{array}$ & $\begin{array}{l}\text { Test with } \\
\text { ouabain* }\end{array}$ & $\begin{array}{c}\% \\
\text { Inhibition }\end{array}$ & $\begin{array}{c}\text { Statistical } \\
\text { significance } \dagger\end{array}$ \\
\hline Mucosal & $5.63 \pm 0.36(4)$ & $4.08 \pm 0.36(4)$ & 27.5 & $p<0.025$ \\
\hline Serosal & $6.56 \pm 0.57(4)$ & $3.47 \pm 0.17(4)$ & 47 & $p<0.005$ \\
\hline \multirow{2}{*}{$\begin{array}{l}\text { Serosal + } \\
\text { mucosal }\end{array}$} & $5.71 \pm 0.69(4)$ & $2.72 \pm 0.42(4)$ & 52 & $p<0.005$ \\
\hline & $\begin{array}{c}\text { Control } \\
\text { preincubation } \\
\text { without } \\
\text { ouabain }\end{array}$ & $\begin{array}{l}\quad \text { Test } \\
\text { preincubation } \\
\text { with ouabain }\end{array}$ & & \\
\hline \multirow{2}{*}{$\begin{array}{l}\text { Serosal }+ \\
\text { mucosal }\end{array}$} & $5.97 \pm 0.35(6)$ & $2.95 \pm 0.18(6)$ & 51 & $p<0.005$ \\
\hline & $\begin{array}{l}\text { Test with } \\
\text { ouabain, } \\
\text { without } \\
\text { preincubation }\end{array}$ & $\begin{array}{l}\text { Test with } \\
\text { ouabain, with } \\
\text { preincubation }\end{array}$ & & \\
\hline \multirow{3}{*}{$\begin{array}{l}\text { Serosal + } \\
\text { mucosal }\end{array}$} & $2.72 \pm 0.42(4)$ & $2.95 \pm 0.18(6)$ & & NS \\
\hline & $\begin{array}{c}\text { Control } \\
\text { without } \\
\text { ouabain, } \\
\text { without } \\
\text { preincubation }\end{array}$ & $\begin{array}{c}\text { Control } \\
\text { without } \\
\text { ouabain, with } \\
\text { preincubation }\end{array}$ & & \\
\hline & $5.71 \pm 0.69(4)$ & $5.97 \pm 0.36(6)$ & & NS \\
\hline
\end{tabular}

* Mean values \pm SEM of the number of experiments in parentheses. Units are $\mu \mathrm{mol}$ transported $/ \mathrm{g}$ wet $\mathrm{wt}$ tissue $/ 30 \mathrm{~min}$.

+ Determined by $t$ test.

of these segments and the effect of $1 \mathrm{mM}$ ouabain on citrulline transport was subsequently measured. Note that ouabain was present on both serosal and mucosal surfaces during the course of the uptake measurements. The results (Table 2) show that the percentage of inhibition by ouabain was similar to that without preincubation. Furthermore, no significant difference was observed between preincubation and no preincubation in control tissues (Table 2), suggesting negligible morphologic damage due to prolonged incubation at room temperature, at least with respect to "downhill" transport of $2 \mathrm{mM}$ citrulline.

Effect of metabolic inhibitors. Intestinal transport of citrulline was investigated in the presence of the electron-transport chain uncoupler dinitrophenol and the inhibitors of active transport, sodium cyanide and sodium azide. Inhibitors were present in both serosal and mucosal fluids. The results show that the transmural transport of citrulline was significantly inhibited (Table 3). These observations suggest that intestinal transport of citrulline is both $\mathrm{Na}^{+}$and energy dependent.

Effect of amino acid analogues on intestinal transport of citrulline. Table 4 shows the effects of monoamino monocarboxylic acids (neutral), diamino monocarboxylic acids (basic), mon- oamino dicarboxylic acids (acidic), imino acids, and keto acids on citrulline transport. The results show that cysteine, leucine, and methionine caused maximal inhibition, followed by proline $\beta$-Alanine, sarcosine, and 2-(methylamino)-isobutyric acid had no effect. The dibasic amino acid lysine had a moderate but statistically significant effect $(p<0.005)$. The acidic amino acid glutamate caused partial $(p<0.005)$ inhibition, but aspartate had no effect. Interestingly, the neutral derivatives of glutamate, glutamine, and glutamic acid- $\gamma$ methyl ester caused a significant $(p<0.005)$ inhibition. L-Serine caused 53\% inhibition, whereas its acidic derivative L-serine sulfate had no effect. Finally, the keto acid by-products of glutamate and aspartate metabolism, oxoloacetate and $\alpha$-oxoglutarate, had no effect. Most of the inhibitors were tested at concentrations at least five times the substrate concentration of citrulline at $5 \mathrm{mM}$. Note that the concentration of L-citrulline chosen was one that would exhibit active transport $(5 \mathrm{mM})$

\section{DISCUSSION}

Although L-citrulline is an important intermediate of urea cycle products, namely a key precursor for arginine biosynthesis, the mechanisms by which it is absorbed via various cell types are not known. Such information would be useful under conditions where the availability of urea cycle intermediate become rate limiting due to genetic or other pathophysiologic manifestations. Our study discusses the mechanisms by which the small intestine handles L-citrulline availability.

Optimal site of absorption. The maximal transport site for transmural transport of L-citrulline was middle to lower ileum in the rat intestine (between 60 and $90 \mathrm{~cm}$ from the pyloric end). In general, carrier-mediated active transport of a given solute may vary with different regions of the intestine. In addition, different species may exhibit different rates of uptake. Factors include the density of carrier sites and their specificity (or affinity) for the solute at a given locus in the intestine and the extent to which the solute may be metabolized in different regions of the intestine (19). Earlier studies showed that, in the human intestine, protein digestion products were well absorbed from the midsmall intestine (20). For free amino acids, Adibi (21), using intraluminal perfusion techniques, reported that methionine, leucine, and threonine were absorbed best from the jejunum. In the rat, experiments with free amino acids have shown that the proximal and mid-small intestine absorbs L-cystine, L-cysteine, and L-valine $(22,23)$, whereas the lower jejunum to upper ileum was found to absorb L-leucine (24). Similar observations have been made with monoamino monocarboxylic acids in the hamster intestine (10).

Evidence for active transport. Transport against the concentration gradient was observed across the rat small intestine in vitro at low initial concentrations of 1 and $5 \mathrm{mM}$, but not at $10 \mathrm{mM}$. Several investigators have observed similar results with other amino acids (24-26). These observations suggest that in testing a compound for active transport it is advisable to start at low concentrations because they are likely to give large concentration

Table 3. Effect and metabolic inhibitors on transport of L-citrulline in rat small intestine*

\begin{tabular}{|c|c|c|c|c|c|}
\hline \multirow{2}{*}{$\begin{array}{l}\text { L-Citrulline } \\
\text { concentration }\end{array}$} & \multirow[b]{2}{*}{ Inhibitor } & \multicolumn{2}{|c|}{$\begin{array}{l}\text { L-Citrulline transport } \dagger \\
(\mu \mathrm{mol} / \mathrm{g} \text { wet } \mathrm{wt} / 30 \mathrm{~min})\end{array}$} & \multirow[b]{2}{*}{$\%$ Inhibition } & \multirow{2}{*}{$\begin{array}{c}\text { Statistical } \\
\text { significance }\end{array}$} \\
\hline & & Control & Test & & \\
\hline 5 & $\operatorname{DNP}(0.2 \mathrm{mM})$ & $11.30 \pm 0.56(4)$ & $3.68 \pm 0.43(4)$ & 67 & $p<0.005$ \\
\hline 5 & $\mathrm{NaCN}(2 \mathrm{mM})$ & $7.80 \pm 1.01(6)$ & $3.29 \pm 0.41(6)$ & 60 & $p<0.005$ \\
\hline 5 & $\mathrm{NaN}_{3}(2 \mathrm{mM})$ & $8.00 \pm 0.95(4)$ & $2.65 \pm 0.15(4)$ & 67 & $p<0.005$ \\
\hline
\end{tabular}

* About six to eight sacs were prepared from each rat intestine. Inhibitor was present on both the serosal and the mucosal side of each sac. Control sacs containing no inhibitor alternated with sacs containing inhibitor. Two sacs each containing $0.4 \mathrm{~mL}$ of the test solution with or without inhibitor were placed in a 50-mL flask containing $15 \mathrm{~mL}$ of the incubation medium. DNP, dinitrophenol: $\mathrm{NaCN}$, sodium cyanide; $\mathrm{NaN}_{3}$, sodium ozide.

+ Values are mean absorption \pm SEM of the number of experiments in parentheses.

$¥$ Determined by $t$ test. A probability value of $p<0.005$ is considered significant. 
Table 4. Effect of other amino acids on transport of $5 \mathrm{mM}$ L-citrulline in rat small intestine*

\begin{tabular}{|c|c|c|c|c|}
\hline \multirow[b]{2}{*}{ Inhibitor } & \multicolumn{2}{|c|}{$\begin{array}{l}\text { L-Citrulline transport } \dagger \\
(\mu \mathrm{mol} / \mathrm{g} \text { wet } \mathrm{wt} / 30 \mathrm{~min})\end{array}$} & \multirow{2}{*}{$\begin{array}{c}\% \\
\text { Inhibition }\end{array}$} & \multirow{2}{*}{$\begin{array}{c}\text { Statistical } \\
\text { significance }\end{array}$} \\
\hline & Control & Test & & \\
\hline 1.-Methionine & $11.90 \pm 1.57(7)$ & $3.94 \pm 0.46(7)$ & 67 & $p<0.005$ \\
\hline 1.-Leucine & $8.40 \pm 0.55$ & $4.01 \pm 0.70(7)$ & 53 & $p<0.005$ \\
\hline 1.-Proline & $9.42 \pm 0.51$ & $5.77 \pm 0.68(6)$ & 39 & $p<0.005$ \\
\hline I.-Serine & $8.81 \pm 0.43(8)$ & $4.25 \pm 0.23(8)$ & 52 & $p<0.005$ \\
\hline I.-Sarcosine & $11.50 \pm 1.00(6)$ & $11.40 \pm 0.77(5)$ & & NS \\
\hline$\beta$-Alanine & $10.70 \pm 1.09(4)$ & $9.67 \pm 1.53(4)$ & & NS \\
\hline 1.-Lysine & $10.60 \pm 0.78(6)$ & $7.67 \pm 0.31(6)$ & 27 & $p<0.005$ \\
\hline 1.-Glutamate & $8.81 \pm 0.45(14)$ & $7.07 \pm 0.63(14)$ & 19 & $p<0.005$ \\
\hline L-Aspartate & $8.82 \pm 0.82(4)$ & $7.77 \pm 0.51(4)$ & 12 & $p<0.15$ (NS) \\
\hline L.-Serine sulphate $\left(\mathrm{Na}^{+}\right)$ & $11.60 \pm 0.68(4)$ & $13.60 \pm 0.12(4)$ & & NS \\
\hline $\begin{array}{l}\text { Glutamic acid } \lambda \text {-methyl } \\
\text { ester }\end{array}$ & $8.14 \pm 1.34(4)$ & $3.10 \pm 0.25(4)$ & 74 & $p<0.005$ \\
\hline 1.-Glutamine & $7.79 \pm 0.78(8)$ & $3.90 \pm 0.45(8)$ & 50 & $p<0.005$ \\
\hline Oxaloacetic acid & $10.80 \pm 0.75$ & $11.10 \pm 1.34(4)$ & & NS \\
\hline$\alpha$-Oxo-glutarate & $11.60 \pm 2.46(4)$ & $11.40 \pm 1.98(4)$ & & NS \\
\hline
\end{tabular}

* Each inhibiting amino acid was at $25 \mathrm{mM}$ concentration. All other technical details as in Table 3.

$\dagger$ Values are mean absorption \pm SEM of the number of experiments in parentheses.

$\ddagger$ Determined by $t$ test. A probability value of $p<0.05$ was considered significant.

gradients, whereas at high initial concentrations no gradient may be established. The importance of working at lower initial concentrations becomes more apparent if the solute transport is $\mathrm{Na}^{+}$ dependent. Low solute levels will minimize the solute-induced distortion of electrochemical potential and thereby maximize the observed magnitude of solute gradients established (27).

The cardiac glycoside ouabain, which inhibits $\mathrm{Na}^{+}-\mathrm{K}^{+}-$stimulated ATPase, inhibited L-citrulline transport significantly. Interestingly, the presence of $\mathrm{mM}$ ouabain on the mucosal solution caused $28 \%$ inhibition of transmural transport of $2 \mathrm{mM}$ citrulline. However, the inhibition was much grater when ouabain was placed on the serosal side $(47 \%)$. It is possible that the mucosal inhibition was due to some of the ouabain crossing the mucosal membranes, across the muscle layers, and then exerting its effect on the ouabain-sensitive $\mathrm{Na}^{+}-\mathrm{K}^{+}$ATPase located at the serosal membrane. According to Stirling (28), this would appear to be unlikely, inasmuch as the permeability of ${ }^{3} \mathrm{H}$-ouabain across the rabbit mucosal membranes was very low. In contrast, Lauterbach (29) showed that, in the rat, ouabain and other glycosides were able to cross the intestinal cells in vitro, the movement displaying the properties of saturable transport systems. In our studies, the inhibitory effect was greatest when $1 \mathrm{mM}$ ouabain was present on both sides of the sac, suggesting the presence of a small amount of ouabain-sensitive $\mathrm{Na}^{+}-\mathrm{K}^{+}$ATPase activity at the mucosal membranes. This would support the early observations by Berg and Chapman (30), who showed the presence of $\mathrm{Na}^{+} \cdot \mathrm{K}^{+}$ATPase in the brush border membranes of the rat intestinal epithelium.

Another interesting feature of our study suggests that the ouabain-sensitive $\mathrm{Na}^{+}-\mathrm{K}^{+}$ATPase may not be the only driving force for the $\mathrm{Na}^{+}$-dependent transmural transport of citrulline. For instance, replacement of $\mathrm{Na}^{+}$buffer with potassium buffer caused $92 \%$ inhibition of $2 \mathrm{mM}$ citrulline transport, whereas the presence of ouabain on both sides of the everted sac (including preincubation) caused a maximum of $52 \%$ inhibition. These observations suggest that a considerable portion (at least $40 \%$ ) of citrulline transport across the rat small intestine is $\mathrm{Na}^{+}$dependent, but not via the ouabain-sensitive $\mathrm{Na}^{+}$pump. It is possible that prolonged incubation of the intestine in $\mathrm{Na}^{+}$-free buffer could cause irreversible damage to the $\mathrm{Na}^{+}$pump mechanisms (31). We investigated this possibility by preincubating the middle to lower region of the rat ileum for $30 \mathrm{~min}$ (in potassium buffer and then replacing it in normal sodium buffer. A segment of intestine (control) was preincubated in Krebs sodium buffer for similar periods. In contrast to the results of Robinson (31), our results showed a remarkable recovery $(88 \%)$ by the rat small intestine, as measured with the transmural transport of $2 \mathrm{mM}$ citrulline. Similar observations were made for alanine transport (32).

Sodium-dependent amino acid transport has been demonstrated across everted gut preparations for tyrosine and valine in the rat (33), for tryptophan, lysine, and methionine in the hamster $(34,35)$, and for glycine, lysine, methionine, and alanine in the rabbit $(36,37)$. Recent studies with vesicle preparations from brush border and basolateral membranes from small intestine have demonstrated the specific presence of $\mathrm{Na}^{+}$-dependent and $\mathrm{Na}^{+}$-independent amino acid transport systems (38), most of which are analogous to the transport systems characterized for nonepithelial cells by Christensen and coworkers (39-41). The specifics of these systems as they relate to citrulline transport are discussed later.

The absorption of citrulline across the rat small intestine was inhibited significantly in the presence of the electron transport chain uncoupler 2,4 dinitrophenol and inhibitors of the respiratory chain, sodium azide and sodium cyanide. Inhibitors were placed on both mucosal and serosal solutions. All three inhibitors showed consistent degrees of inhibition (Table 1). These observations confirm active transport of citrulline across the rat small intestine.

The apparent $\mathrm{K}_{1}$ value for the $\mathrm{Na}^{+}$-dependent citrulline transport across the everted rat small intestine was $4.10 \pm 0.86 \mathrm{mM}$. Note, this parameter may be subject to change, depending on the degree of unstirred water layer around the brush border membranes (42). In our opinion, however, shaking the flasks containing everted sacs at $80 \mathrm{cycles} / \mathrm{min}$ would reduce the unstirred water layer effect without excessive morphologic damage to the brush border membranes of the epithelium (43). Similar magnitudes have, however, been observed for the $\mathrm{K}_{\mathrm{t}}$ values of leucine, valine, methionine, and tyrosine in the everted small intestine of the rat (24), leucine in the rabbit ileum (44), and leucine and valine in the everted small intestine of the hamster (25), and phenylalanine transport across the brush border membranes of the rabbit jejunum (38).

Inhibition studies with other amino acids suggest that, from the various transport groups considered, L-citrulline appears to have the greatest affinity for the neutral amino acid pathway. Among the neutral amino acids, the order of inhibition of citrulline absorption was as follows: cysteine $>$ glutamic acid- $\gamma$ methyl ester $>$ methionine $>$ leucine $>$ serine $>$ proline. $\beta$ Alanine, sarcosine, and 2-(methylamino)-isobutyric acid had no 
effect. Inhibition by the basic amino acid lysine was less than that by the neutral amino acids; however, the difference was significant $(p<0.005)$. Of the acidic amino acids, glutamate caused a small but significant inhibition $(p<0.025)$. We speculate that the inhibition by lysine and glutamate may be noncompetitive.

Since the studies of Christensen and colleagues (39-41), a number of amino acid transport systems have been described in nonpolarized cells and a few polarized epithelial cells. These include for the zwitterionic amino acids the $\mathrm{Na}^{+}$-dependent systems $\mathrm{A}, \mathrm{ASC}, \mathrm{N}$, and Gly (39-41), and the $\mathrm{Na}^{+}$-independent systems L1, L2, T, $\mathrm{B}^{0+}$, and asc (45-49). Many of these transport systems have been identified in epithelial cells of the kidney (5053) and intestine $(54,55)$. Stevens et al. $(38)$, have described additional systems for the brush border membranes of the rabbit jejunum, specifically, an $\mathrm{Na}^{+}$-dependent NBB system that handles most neutral amino acids, except MeAIB, a model substrate for system $A(39,40)$. NBB is thought not to be ASC, because it does not serve glycine and phenylalanine (38). There is also a PHE (phenylalanine preferring) system that handles primarily phenylalanine and methionine (38). Karasov et al. (56) have reported at least six major classes of amino acid transport systems in everted gut sleeve and sac preparations from the mouse intestine. These include the following: 1) an $\mathrm{Na}^{+}$-dependent pathway for neutral amino acids; 2) an $\mathrm{Na}^{+}$-dependent pathway for basic amino acids, shared to various degrees by neutral amino acids; 3) an $\mathrm{Na}^{+}$-dependent pathway for the imino acid proline; 4) an $\mathrm{Na}^{+}$-dependent pathway for acidic amino acids; 5) an $\mathrm{Na}^{+}$independent pathway for neutral and basic amino acids, with low affinity for imino acids or acidic amino acids; and 6) an $\mathrm{Na}^{+}$-independent pathway for acidic amino acids. Leucine and methionine share a "public" transporter for neutral amino acids in mouse intestine (56). This system is perhaps the same or similar to the NBB system described for the brush border membranes of the rabbit jejunum (38).

Our results suggest that $\mathrm{L}$-citrulline transport in the rat occurs predominantly by the NBB system described for the rabbit jejunum or the "public" leucine and methionine preferring system in the mouse intestine. Another property that L-citrulline shares with methionine and leucine is that it is rapidly transported at low concentrations but has a low maximal transport velocity and is slowly transported at high concentrations. Cysteine, a suitable substrate for system ASC in the rat hepatocyte (57) and the Ehrlich ascites cells (58), caused a dramatic inhibition of citrulline transport in rat intestine (Table 3). Although vesicle studies with the rabbit jejunum suggest the presence of system ASC at the basolateral membranes (38), its precise location in the rat intestinal epithelium has not been determined. It is therefore likely that, if ASC does exist at the brush border membranes of the rat intestine, citrulline could selectively use this pathway. Hayashi and Kawasaki (59) have suggested the presence of both systems A and ASC in brush border membranes from guinea pig intestine.

Lack of inhibition by lysine confirms that citrulline migration across the intestinal mucosa is independent of the dibasic carrier $\mathrm{y}^{+}$specific for the uptake of lysine, arginine, and ornithine, and it is this transport system that is defective at the basolateral membranes of renal and intestinal membranes in patients with LPI. Another subject that requires some discussion is the source and fate of circulating citrulline. Windmueller and Spaeth (60) made an important study that demonstrated that the rat liver does not contribute significantly to the levels of citrulline in the circulation. Their data suggest that the intestine remains the primary tissue so far identified that normally releases significant amounts of citrulline into the blood and that the intestinal-renal pathway accounts for a large but still unmeasured portion of citrulline turnover in the circulation. Furthermore, Milner and Visek (61) showed that increased needs for growth can be met by feeding arginine and citrulline, but not ornithine. Hence, the availability of citrulline is rate-limiting, and therefore the intestinal route remains critical.

Acknowledgments. The authors thank Dr. Adam Jonas for critical evaluation of this manuscript and Leslie Sugahara for secretarial assistance.

\section{REFERENCES}

1. Charles R, Tager JM, Slater EC 1967 Citrulline synthesis in rat-liver mitochondria. Biochim Biophys Acta 131:29-4

2. Christensen E. Brandt NJ. Philips J 1980 Citrullinaemia: the possibility of prenatal diagnosis. J Inherited Metab Dis 3:73-75

3. Evered DF 1956 The excretion of amino acids by the human. A quantitative study with ion-exchange chromatography. Biochemistry 62:416-427

4. Bergeron M. Gougoux A 1989 The Renal Fanconi Syndrome. In: Scriver CR, Beaudet AL, Sly WS, Valle D(eds) The Metabolic Basis of Inherited Diseases, Vol 104. McGraw Hill, New York, pp 2569-2580

5. Rajantie J. Simell O, Perheenhupta J 1980 Intestinal absorption in lysinuric protein intolerance. Gut 21:519-524

6. Evered DF. Nunn PB 1968 Uptake of amino acids by mucosa of rat colon in vitro. Eur J Biochem 4:301-304

7. Lin ECC, Hagihara H, Wilson TH 1962 Specificity of the transport system for neutral amino acids in the hamster intestine. Am J Physiol 202:919-925

8. Wilson TH, Wiseman G 1954 The use of sacs of everted small intestine for the study of the transference of substances from the mucosal to the serosal surface. J Physiol (Lond) 123:116-125

9. Krebs HA, Henseleit K 1932 Untersuchungen uber die Harnstoffbildung in Tierkorper. Hoppe-Seylers Z Physiol Chem 210:33-66

10. Levine RR, McNarg WF, Kornguth PJ, Le Blanc R 1970 Histological reevaluation of everted gut technique for studying intestinal absorption. Eur $\mathbf{J}$ Pharmacol 9:211-219

11. White $\mathrm{HH} 1968$ Separation of amino acids in physiological fluids by twodimensional thin-layer chromatography. Clin Chim Acta 21:297-302

12. Evered DF. Hargreaves BMC 1973 Uptake of amino acids by rat small intestine and kidney cortex in vitro. Xenobiotica 3:753-757

13. Prescott LM, Jones ME 1969 Modified methods for the determination of carbamyl aspartate. Anal Biochem 32:408-419

14. Cleland WW 1967 The statistical analysis of enzyme kinetic data. In: Nord FF (ed) Advances in Enzymology. Interscience. John Wiley and Sons. New York, pp $1-32$

15. Csaky TZ, Hara Y 1965 Inhibition of active intestinal sugar transport. Am J Physiol 209:467-472

16. Field M. Schultz SG, Curran PF 1967 Alanine transport across isolated rabbit ileum. Biochim Biophys Acta 135:236-243

17. Newey H. Sanford PA. Smyth DH 1968 Some effects of ouabain and potassium on transport and metabolism in rat small intestine. J Physiol (Lond) 194: 237-248

18. Schultz SG, Curran PF 1970 Coupled transport of sodium and organic solutes. Physiol Rev 50:637-718

19. Lepper K. Mailmann DS 1977 An ultrastructural examination of everted rat jejunum. Life Sci 20:1697-1704

20. Nixon SE, Mawer GE 1970 The digestion and absorption of protein in man. 1. The site of absorption. Br J Nutr 24:227-240

21. Adibi SA 1969 The influence of molecular structure of neutral amino acids on their absorption kinetics in the jejunum and ileum of human intestine in vivo. Gastroenterology 56:903-913

22. Neil MW 1959 The absorption of cystine and cysteine from rat small intestine. Biochem J 71:118-124

23. Reiser S, Christiansen PA 1965 Intestinal transport of amino acids studied with L-valine. Am J Physiol 208:914-924

24. Larson PR, Ross JE. Tapley DF 1964 Transport of neutral, dibasic and Nmethyl-substituted amino acids by rat intestine. Biochim. Biophys Acta 88: 570-577

25. Matthews DM, Laster L 1965 Kinetics of intestinal active transport of five neutral amino acids. Am J Physiol 208:593-600

26. Spencer RP, Samiy AH 1960 Intestinal transport of L-tryptophan in vitro. Am J Physiol 199:1033-1036

27. Kimmich GA, Carter-Su C 1978 Membrane potentials and the energetics of intestinal $\mathrm{Na}^{+}$-dependent transport systems. Am J Physiol 235:C73-C81

28. Stirling CE 1967 High-resolution radioautography of phlorizin- ${ }^{3} \mathrm{H}$ in rings of hamster intestine. J Cell Biol 35:605-618

29. Lauterbach F 1968 Comparison of intestinal penetration of cortisol and convallatoxin: demonstration of a transport mechanism for cardiotonic steroids. Biochim Biophys Acta 150:146-155

30. Berg GG, Chapman B 1965 The sodium and potassium activated ATPase of intestinal epithelium. I. Location of enzymatic activity in the cell. J Cell Comp Physiol 65:361-372

31. Robinson JWL 1967 The loss of intestinal transport capacity following preincubation in sodium-free media in vitro. Pfluegers Arch 294:182-200

32. Schultz SG, Curran PF, Chez RA, Fuisz RE 1967 Alanine and sodium fluxes across mucosal border of rabbit ileum. J Gen Physiol 50:1241-1260

33. Harrison HE, Harrison HC 1963 Sodium, potassium, and intestinal transport of glucose, 1-tyrosine, phosphate, and calcium. Am J Physiol 205:107-111

34. Cohen LL, Huang.KC 1964 Intestinal transport of tryptophan and its derivative.s Am J Physiol 206:647-652

35. Binder HJ, Boyer M, Spiro HM, Spencer RP 1966 Species differences in the 
response of amino acid transport to ouabain and sodium-free medium. Comp Biochem Physiol [A] 18:83-89

36. Field M. Schultz SG, Curran PF 1967 Alanine transport across isolated rabbit ileum. Biochim Biophys Acta 135:236-243

37. Rosenberg IH, Coleman AL, Rosenberg LE 1965 The role of sodium ions in the transport of amino acids by the intestine. Biochim Biophys Acta 102: |61-17|

38. Stevens BR, Kaunitz JD, Wright EM 1984 Intestinal transport of amino acids and sugars: advances using membrane vesicles. Annu Rev Physiol 46: 417-433

39. Oxender DL, Christensen HN 1963 Distinct mediating systems for the transport of neutral amino acids by the Ehrlich cell. J Biol Chem 238 : 3686-3699

40. Christensen HN 1990 Role of amino acid transport and countertransport in nutrition and metabolism. Physiol Rev 70:43-71

41. Christensen HN 1989 Distinguishing amino acid transport systems of a given cell or tissue. In Fleischer S, Fleischer B (eds) Methods in Enzymology. Biomembranes, Vol 173. Academic, New York, pp 576-616

42. Wilson FA, Dietschy JM 1974 The intestinal unstirred layer: its surface area and effect on active transport kinetics. Biochim Biophys Acta 363:112-126

43. Thomson ABR. Dietschy JM 1984 The role of the unstirred water layer in intestinal permeation. Hand Exp Pharm 70:165-269

44. Curran PF, Schultz SG, Chez RA, Fuisz RE 1967 Kinetic relations of the $\mathrm{Na}^{+}$amino acid interaction at the mucosal border of intestine. J Gen Physiol 50: $1261-1286$

45. Weissbach L. Handlogten ME, Christensen HN, Kilberg MS 1982 evidence for two $\mathrm{Na}^{+}$-independent neutral amino acid transport systems in primary cultures of rat hepatocytes. J Biol Chem 257:12006-12011

46. Rosenberg R, Young JD. Ellory JC 1980 L-Tryptophan transport in human red blood cells. Biochim Biophys Acta 598:374-384

47. Vadgama JV. Christensen $\mathrm{HN} 1985$ Discrimination of $\mathrm{Na}^{+}$-independent transport systems $\mathrm{L}, \mathrm{T}$, and asc in erythrocytes. $\mathrm{Na}^{+}$-independence of the latter a consequence of cell maturation? J Biol Chem 260:2912-2921

48. Fincham DA, Mason DK, Young JD 1985 Characterization of a novel $\mathrm{Na}^{+}$. independent amino acid transporter in horse erythrocytes. Biochem $\mathrm{J} 227$ : 13-20

49. Van Winkle LJ, Campione AL, Gorman JM $1988 \mathrm{Na}^{+}$-independent transport of basic and zwitterionic amino acids in mouse blastocystes by a shared system and by processes which distinguishes between these substrates. J Biol Chem 263:3150-3163

50. Rabito CA, Karish MV 1982 Polarized amino acid transport by an epithelial cell line of renal origin (LLC-PK). The apical systems. J Biol Chem 257: 6802-6808

52. Sepulveda FV, Pearson JD 1982 Characterization of neutral amino acid uptake by cultured epithelial cells from pig kidney. J Cell Physiol 112:182-188

52. Boerner P. Saier Jr MH 1982 Growth regulation and amino acid transport in epithelial cells: influence of culture conditions and transformations on $A$ ASC, and L transport activities. J Cell Physiol 113:240-246

53. Kuhlmann MK, Vadgama JV 1991 Characteristics of threonine transport into a kidney epithelial cell line (BSC-1). Evidence for the presence of $\mathrm{Na}^{+}$. independent system asc. J Biol Chem 266:15042-15047

54. Mircheff AK, Van Os CH, Wright EM 1980 Pathways for alanine transport in intestinal basal lateral membrane vesicles. J Membr Biol 52:83-92

55. Stevens BR, Ross HJ, Wright EM 1982 Multiple transport pathways for neutral amino acids in rabbit jejunal brush border vesicles. J Membr Biol 66: 213-225

56. Karasov WH, Solberg DH, Carter S. Hughes M, Phan D, Zollman F, Diamond JM 1986 Dependence of amino acid uptake by mouse intestine ion dietary protein or amino acid levels. Am J Physiol 251:G614-G625

57. Kilberg MS, Handlogten ME, Christensen HN 1979 Cysteine as a systemspecific substrate for transport system ASC in rat hepatocytes. Biochem Biophys Res Commun 88:744-751

58. Christensen HN 1984 Organic ion transport during seven decades. The amino acids. Biochim Biophys Acta 779:255-269

59. Hayashi K, Kawasaki T 1982 The characteristic changes in amino acid transport during development in brush border membrane vesicles of the guinea pig ileum. Biochim Biophys Acta 691:83-90

60. Windmueller HG, Spaeth AE 1981 Source and fate of circulating citrulline. Am J Physiol 241:E473-E480

61. Milner JA, Visek WJ 1975 Urinary metabolites characteristic of urea-cycle amino acid deficiency. Metabolism 24:643-651 